\title{
Serial estimation of serum C-reactive protein and procalcitonin for early detection of anastomotic leak after elective intestinal surgeries: a prospective cohort study
}

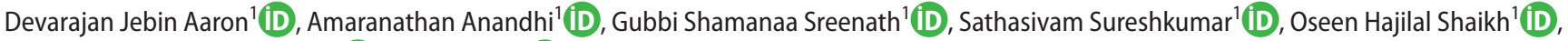
Vairrappan Balasubramaniyan² (D), Vikram Kate ${ }^{1}$ (D)

1 Department of Surgery, Jawaharlal Institute of Postgraduate Medical Education and Research, Puducherry, India

${ }^{2}$ Department of Biochemistry, Jawaharlal Institute of Postgraduate Medical Education and Research, Puducherry, India

\begin{abstract}
Objective: Anastomotic leak can adversely affect the outcome of surgery especially if detected late. The present study was carried out to detect the anastomotic leak early in the postoperative period using serial estimation of procalcitonin (PCT) and C-reactive protein (CRP).

Material and Methods: A single centre prospective cohort study was done on patients undergoing elective gastrointestinal surgery with anastomosis. Serial estimation of serum procalcitonin and $\mathrm{C}$ reactive protein was done on the first five postoperative days. Other parameters such as hemoglobin, total protein, albumin and WBC counts were noted perioperatively. Patients were followed up to 60th postoperative day to assess for anastomotic leak, wound infection and other septic foci.

Results: Eighty-four patients were included in the study. Anastomotic leak rate was 26.19\% (22/84) and 3/22 patients died in the anastomotic leak group. Wound infection rate was $23.81 \%$. The cut off value of CRP on third postoperative day in detecting anastomotic leak was $44.322 \mathrm{mg} / \mathrm{dl}$ with sensitivity of $72.73 \%$, specificity of $66.13 \%$ and accuracy of $59.52 \%$. The cut off value for WBC count measured perioperatively in detecting anastomotic leak was 9470 cell $/ \mathrm{mm}^{3}$ with sensitivity of $72.73 \%$, specificity of $56.45 \%$ and accuracy of $59.74 \%$. Serum procalcitonin, haemoglobin, total protein and albumin measured were not sensitive enough to detect the anastomotic leak early.
\end{abstract}

Conclusion: Measuring CRP on the third postoperative day can predict anastomotic leak with a cut off value of $44.32 \mathrm{mg} / \mathrm{dl}$. Patients with raised CRP need careful evaluation to rule out anastomotic leak before deciding on early discharge.

Keywords: C-reactive protein, procalcitonin, anastomotic leak

Cite this article as: Aaron DJ, Anandh A, Sreenath GS, Sureshkumar S, Skaikh HO, Balasubramaniyan V, et al. Serial estimation of serum C-reactive protein and procalcitonin for early detection of anastomotic leak after elective intestinal surgeries: a prospective cohort study. Turk J Surg 2021 37 (1): $22-27$

\section{Corresponding Author}

\section{Vikram Kate}

E-mail: drvikramkate@gmail.com

Received: 15.11 .2020

Accepted: 05.03.2021

Available Online Date: 22.03 .2021

O Copyright 2021 by Turkish Surgical Society Available online at www.turkjsurg.com

DOI: $10.47717 /$ turkjsurg.2021.5102

\section{INTRODUCTION}

Anastomotic leak (AL) is the most dreadful complication, which can occur following all intestinal anastomotic surgeries. The incidence of AL following intestinal surgeries is 2-20\% (1). The incidence is high in esophagectomy and colorectal surgeries and has been reported as $10 \%$ and $2-19 \%$ respectively $(2,3)$. Mortality following AL after colorectal and esophageal surgeries are $30 \%$ and $30-60 \%$ respectively $(4,5) 70$ patients undergoing colorectal surgery were prospectively analyzed in a single-center tertiary teaching hospital. Demographic and surgical data were obtained. Serum procalcitonin was taken before surgery and at day 3 (72 hours. AL can present early or late. It is usually diagnosed between 7 to 12 days postoperatively. Late AL presents after one-month postoperatively (6). It is always the priority of any surgeon to identify these ALs at the earliest possible so as to avoid mortality and morbidity.

AL will lead to bacterial contamination of the peritoneal cavity, which leads to rise in inflammatory mediators such as C-reactive protein (CRP) and procalcitonin (PCT) before it presents clinically. AL can be detected early in elective cases, where wound infection and peritoneal contamination are less due to preoperative bowel preparation and prophylactic preoperative antibiotics. Some studies have reported the role of PCT and CRP for early detection of AL in a group of specific surgery like colorectal and oesophageal surgery $(3,4,7-10)$ it is clinically valuable to detect anastomotic leak early after esophagectomy in esophageal cancer. The purpose of this study is to investigate the associations between routine postoperative laboratory findings and anastomotic leak and to analyze the laboratory findings to find out an independent 
predictive marker for anastomotic leak. In addition, this study compares cases treated with neoadjuvant therapy (NT. However, there are not many reports documenting the efficacy of these parameters in overall alimentary tract surgery.

This study was carried out to determine the role of PCT and CRP plasmatic concentration as an early detector of AL following elective gastrointestinal surgery.

\section{MATERIAL and METHODS}

This study was a prospective cohort study carried out in a tertiary centre in India. Institutional ethics committee approval was obtained (JIP/IEC/201/1040). Written Informed consent was taken from all participants in this study, and patients were given full freedom to withdraw at any point of time during the study.

Patients and data collection:

All patients aged more than or equal to 18 years of age, who had undergone elective gastrointestinal surgery with an anastomosis, were included in the study. Patients with fever or focus of sepsis preoperatively, patients who had received intraperitoneal chemotherapy and in patients in whom covering stoma was done with anastomosis were excluded from the study.

All patients, who had fulfilled the inclusion and exclusion criteria, were included in the study after taking informed written consent. Following surgery, blood was collected daily at 8 am on the first five postoperative days for PCT and CRP measurement.

CRP levels were estimated using ELISA kit manufactured by Calbiotech USA® (11). PCT levels were estimated using ELISA kit manufactured by Raybiotech ${ }^{\circledR}$ (12). Normal reference value of PCT as per the kit was less than $0.15 \mathrm{ng} / \mathrm{ml}$, and the normal reference value of CRP was less than $3 \mathrm{mg} /$.

Patient data, such as age, sex, telephone number, diagnosis, indication for surgery, previous surgical history, perioperative hemoglobin, total leucocyte counts (TLC), total protein and albumin were recorded. Hemoglobin and TLC were measured using Sysmex Xt-2000i which works on Coulter principle (13). Albumin was measured in Beckman-Coulter AU5800 using spectophotometry method and bromocresol green was used as dye. Total protein was measured in Beckman-Coulter AU5800 using photometric biuret end point method (14). Confounding variables such as surgical site infection and any other postoperative septic foci were also noted. Patients were followed up postoperatively for any signs and symptoms of leak and any other postoperative complications.

AL was defined as any clinical signs of leakage, confirmed by radiological examination, endoscopy, clinical examination of the anastomosis (i.e., palpation of the anastomosis), or reoperation (15). The patient was labeled as having AL if he/she had clinical evidence of leak like peritoneal signs, bile or faecal content in the drain or if ultrasound guided aspiration of the free fluid or localized collection at the anastomotic site revealed bile or faecal mat- ter or if water soluble contrast leak was seen on fluoroscopy or computed tomography.

Serum PCT, CRP, haemoglobin, TLC, total protein and albumin were analysed for the predictability of AL. The incidence of leak following elective intestinal anastomosis in this hospital, the risk factors associated with leak in the population studied, the sensitivity and specificity of serial estimation of serum CRP and PCT to detect leak early were calculated. The patients were followed up on post-operative day (POD) 60 over telephonic interview, and development of enterocutaneous fistula or late post-operative leak were recorded.

\section{Sample Size}

Sample size was calculated using the formula, $N=Z 2 \times P(1-P) /$ [d $2 \times$ (1-prevalence)] when $P$ was specific. The sensitivity of PCT measured for five post-operative days to predict AL was 100\% and specificity was $72 \%$. The specificity of CRP measured for five post-operative days to predict AL was $83 \%$ (8). With expected specificity of $72 \%$ and expected prevalence of AL as $9.4 \%$, the sample size was calculated as 84 with 95\% confidence interval, $10 \%$ relative precision. The specificity of PCT was lower than that of CRP. Hence, sample size was calculated using the specificity of PCT. Power of the study was kept at $80 \%$.

\section{Statistical Analysis}

All statistical analysis was done using SPSS version 20. Categorical variables such as presence of AL were expressed as proportions. Continuous variables such as PCT, CRP, haemoglobin, total protein, albumin and TLC levels were expressed as mean (SD) or median (IQR) depending upon the normality of distribution. Total protein, albumin, haemoglobin and TLC showed normal distribution. CRP and PCT levels measured on all five days did not follow normal distribution. Receiver Operating Characteristic (ROC) curve was plotted between day specific PCT, CRP, perioperative haemoglobin, total protein, albumin, $T L C$ and the presence of $A L$, to determine optimum cut-off value for early detection of AL, using sensitivity and specificity. The differences in haemoglobin, total protein, albumin and TLC between AL and NAL patients were analysed using student $t$ test. PCT and CRP was analysed using Mann Whitney $U$ test. $p$ value less than 0.05 was taken as significant.

\section{RESULTS}

This study was carried out from January 2017 to December 2018. A total of 84 patients were included in the study. Surgical procedures done for the patients were gastric (42), colonic (13), pancreaticobiliary (20), esophageal (3), stoma closure (4) and small bowel surgeries (2). AL developed among 22/84 patients (26.19\%). The distribution of anastomotic leak among various procedures were 12, 3, 6, and 1 in gastric, colonic, pancreaticobiliary and oesophageal anastomosis respectively. AL did not show any statistical difference between sex and different age groups (Table 1). Overall mortality in the study was 5.95\% (5/84). 
Mortality in the AL group $(3 / 22 ; 13.64 \%)$ when compared to the mortality in the NAL group $(2 / 62 ; 3.22 \%)$ although higher, the difference was not significant $(p=0.076)$. The overall incidence of postoperative surgical site infection was 20/84 (23.81\%). The incidence of wound infection in the AL group was $27.27 \%$ and for the NAL group, it was $22.58 \%$. The difference in distribution of wound infection was not statistically significant $(p=0.657)$. Clinical demographic parameters studied in AL and NAL groups are shown in Table 1.

The median and interquartile range for serum CRP and procalcitonin for all five postoperative days were calculated. The area under the curve calculated for CRP on all five postoperative days was above 0.500 (Table 2).

Mean and standard deviation of haemoglobin, TLC, total protein and albumin were calculated. The area under the curve of TLC was found to be significant (Table 3).

\begin{tabular}{|c|c|c|c|}
\hline Patient characteristics & $A L$ group $(n=22)$ & NAL group $(n=62)$ & $\mathrm{p}^{*}$ \\
\hline \multicolumn{4}{|l|}{ Sex } \\
\hline Female $(n=31)$ & $11(35.48 \%)$ & $20(64.52 \%)$ & 0.138 \\
\hline Male $(n=53)$ & $11(20.75 \%)$ & $42(79.25 \%)$ & \\
\hline \multicolumn{4}{|l|}{ Age groups } \\
\hline $18-45$ years $(n=27)$ & $11(40.74 \%)$ & $16(59.26 \%)$ & 0.074 \\
\hline $45-60$ years $(n=27)$ & $7(25.93 \%)$ & $20(74.07 \%)$ & \\
\hline More than 60 years $(n=29)$ & $4(13.79 \%)$ & $25(86.21 \%)$ & \\
\hline Mortality & $3(13.64 \%)$ & $2(3.22 \%)$ & 0.076 \\
\hline Wound infection & $6(27.27 \%)$ & $14(22.58 \%)$ & 0.657 \\
\hline
\end{tabular}

Table 2. Comparison of procalcitonin and CRP between AL and NAL groups

\begin{tabular}{|l|c|c|c|c|c|}
\hline Test & POD & Non-AL group Median (IQR) & AL group Median (IQR) & p* & AUC \\
\hline Procalcitonin & 1 & $210.98(32.43-657.05)$ & $22.06(11.54-206.44)$ & 0.009 & 0.312 \\
\hline Procalcitonin & 2 & $16.27(49.60-652.02)$ & $26.2(15.98-212.99)$ & 0.013 & 0.322 \\
\hline Procalcitonin & 3 & $176.72(39.17-582.03)$ & $7.55(7.4-198.45)$ & 0.002 & 0.274 \\
\hline Procalcitonin & 4 & $216.35(51.82-625.56)$ & $20.456(7.25-261.48)$ & 0.017 & 0.328 \\
\hline Procalcitonin & 5 & $162.64(33.03-450.16)$ & $15.63(7.23-352.36)$ & 0.009 & 0.315 \\
\hline CRP & 1 & $25.04(16.24-35.14)$ & $34.89(29.15-54.89)$ & 0.041 & 0.647 \\
\hline CRP & 2 & $27.82(16.54-41.61)$ & $34.39(27.16-38.08)$ & 0.137 & 0.607 \\
\hline CRP & 3 & $27.09(16.34-53.98)$ & $44.32(35.28-61.37)$ & 0.033 & 0.654 \\
\hline CRP & 4 & $34.90(16.30-58.07)$ & $51.23(30.19-51.23)$ & 0.148 & 0.604 \\
\hline CRP & 5 & $29.44(16.23-48.98)$ & $45.68(32.57-48.51)$ & 0.104 & 0.617 \\
\hline POD: Post & & & & & \\
\hline
\end{tabular}

POD: Post operative day, non AL group-non anastomotic leak group, AL group-anastomotic leak group, AUC: Area under the curve, IQR: Interquartile range, CRP: C-reactive protein.

*Mann Whitney U test.

Table 3. Comparison of hemoglobin, total protein, albumin and TLC between AL and NAL groups

\begin{tabular}{|l|c|c|c|c|}
\hline Test & Non AL group Mean (SD) & AL group Mean (SD) & p $^{*}$ & AUC \\
\hline Hemoglobin & $10.27(1.81)$ & $11(1.76)$ & 0.108 & 0.355 \\
\hline Total protein & $5.6(1.11)$ & $5.62(0.92)$ & 0.945 & 0.452 \\
\hline Albumin & $2.96(0.59)$ & $3.06(0.63)$ & 0.541 & 0.417 \\
\hline TLC & $10131.94(4468.81)$ & $12203.64(4472.41)$ & 0.009 & 0.641 \\
\hline
\end{tabular}

Non AL group: Non anastomotic leak group, AL group: Anastomotic leak group, AUC: Area under the curve, SD: Standard deviation, TLC: Total leucocyte counts. *Student t-test. 


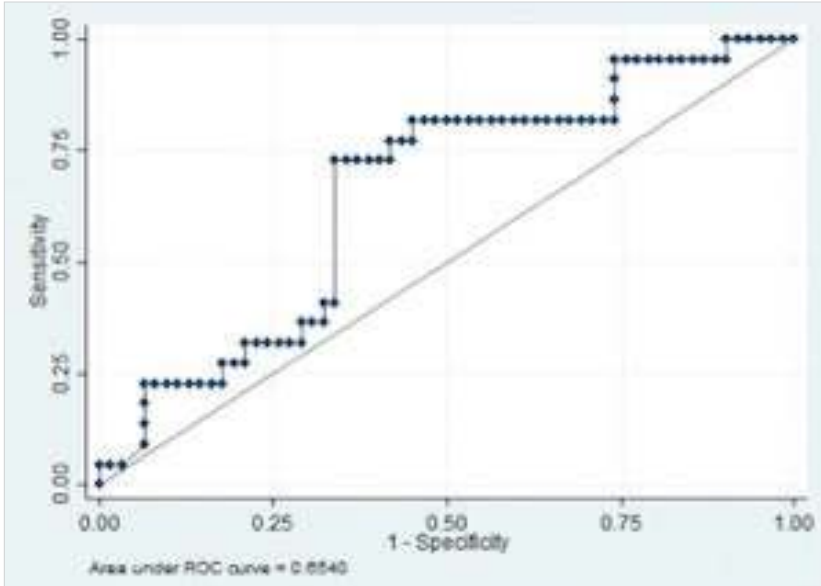

Figure 1. Receiver operating characteristic curve of serum $C$ reactive protein on postoperative day three.

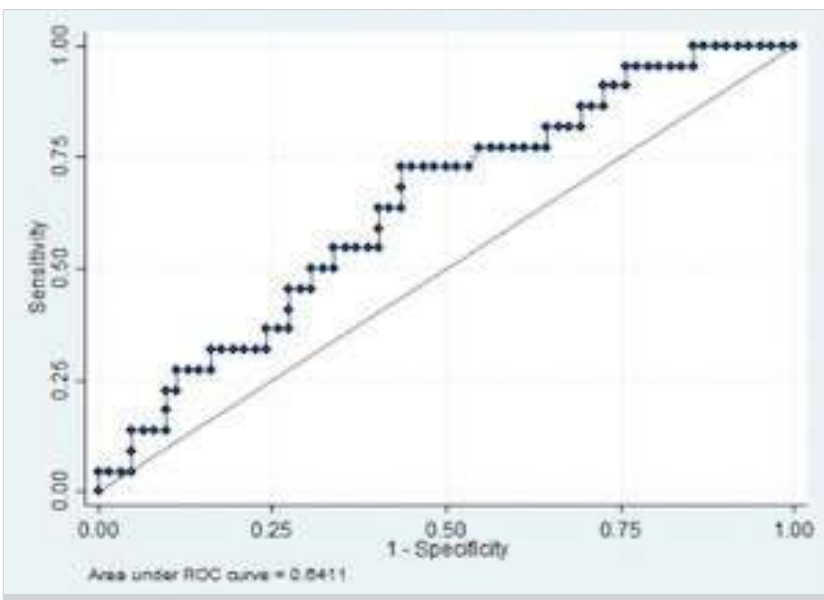

Figure 2. Receiver operating characteristic curve of perioperative total leucocyte count.

AUC for serum CRP was 0.654 on day three reaching the maximum than the other postoperative days. The cut off value was taken as more than $44.32 \mathrm{mg} / \mathrm{dl}$ with a sensitivity of $72.73 \%$ and specificity of $66.13 \%$ (Figure 1) (Table 4). When the cut off value of the perioperative TLC count was taken as more than 9470 cells $/ \mathrm{mm}^{3}$, the sensitivity was $72.73 \%$ and the specificity was $56.45 \%$, (Figure 2) (Table 4). AUC was found to be 0.641 .

\section{DISCUSSION}

$\mathrm{AL}$ is a serious life-threatening complication that can occur after a gastrointestinal anastomosis. It is associated with high mor- tality and morbidity due to the sepsis it causes. Moreover, overall survival reduces as the chance of recurrence of malignancy increases due to delay in adjuvant therapy. Early diagnosis of AL can reduce mortality and morbidity significantly. CRP is an acute phase reactant produced by liver, in response to infection, ischemia and tissue damage (10). It starts to rise two hours following insult and peaks at 48 hours (3). In normal circumstances, the $C$ cells of thyroid gland produce PCT. In sepsis, white blood cells, pancreas, spleen, kidney, colon, adipocytes and the brain produce PCT. It starts rising at 3-4 hours and peaks at 8 to 24 hours (4). In the present study, the aim was to determine whether serological analysis could detect AL prior to its clinical presentation.

The present study showed that the plasmatic concentration of CRP on third POD with a cut off value of more than $44.32 \mathrm{mg} /$ dl was significantly associated with AL. Perioperative TLC, more than 9470 cells $/ \mathrm{mm}^{3}$ had predicted $\mathrm{AL}$ early. Postoperative serum PCT was not an early predictor of AL. Total protein, albumin and hemoglobin level measured perioperatively had no association with $\mathrm{AL}$.

Garcia-Granero et al. have reported about early prediction of AL after colorectal resection using PCT and CRP (8). The study showed that CRP and PCT were reliable predictors from third to fifth postoperative days with AUC more than 0.800. The best predictor was PCT on day five with the cutoff of $0.31 \mathrm{ng} / \mathrm{ml}$, with sensitivity of $100 \%$, specificity of $72 \%$, and negative predictive value of $100 \%$ and positive predictive value of $17 \%$. Aiolfi et al. have reported a systematic analysis and Bayesian meta-analysis on five studies including 850 patients on early prediction of esophageal AL using CRP (9). This study showed that CRP values on POD three and five had very good diagnostic accuracy with the AUC of 0.800 . The cut off values derived for POD three and five were $17.6 \mathrm{mg} / \mathrm{dl}$ and $13.2 \mathrm{mg} / \mathrm{dl}$ respectively. Hayati et al. have reported on early prediction of colorectal $A L$ using serum PCT on POD 3 (4). The study showed that PCT cut off value was $5.29 \mathrm{ng} / \mathrm{ml}$ with sensitivity of $100 \%$, specificity of $85 \%$, the positive predictive value of $23 \%$ and the negative predictive value of $100 \%$. The early predictor of AL associated with pancreaticoduodenectomy surgery was analyzed only in very few studies $(16,17)$. The studies mentioned above showed that the sensitivity and negative predictive value of CRP and PCT in predicting $\mathrm{AL}$ of various surgeries was 100\%. So, these serological tests can be used to rule out $A L$, postoperatively. The present

Table 4. Best cutoff value of CRP and TLC along with AUC, sensitivity and specificity for detecting anastomotic leak

\begin{tabular}{l|c|c|c|c|c|c|c|c|}
\hline Test & POD & AUC & Cut off & Sensitivity & Specificity & Positive predictive value & Negative predictive value & Accuracy \\
\hline CRP & 3 & 0.654 & $44.32 \mathrm{mg} / \mathrm{dl}$ & $72.73 \%$ & $66.13 \%$ & $30 \%$ & $75.93 \%$ & $59.52 \%$ \\
\hline TLC & 0.641 & $9470 \mathrm{cell} / \mathrm{mm}^{3}$ & $72.73 \%$ & $56.45 \%$ & $28.95 \%$ & $89.74 \%$ & $59.74 \%$ \\
\hline
\end{tabular}


study showed that the plasmatic concentration of CRP on third POD was significantly increased in patients with $\mathrm{AL}$ and the serial estimation of serum PCT postoperatively was not associated with AL. This may be because of raised postoperative wound infection rate, which is an important confounding factor.

A meta-analysis has shown that the overall incidence of $A L$ was $9 \%$ (18). In the present study, it was found that the incidence of $A L$ was $26.19 \%$, which was high as many of the patients in present study had hypoalbuminemia, though it did not show any statistical significance. The mean value of albumin in the present study was $2.96 \mathrm{mg} / \mathrm{dl}$ and $3.05 \mathrm{mg} / \mathrm{dl}$ in NAL and AL groups respectively.

Zarnescu et al. have reported the risk factors related to AL in colorectal surgery (19). General factors associated with increased chance of $\mathrm{AL}$ in colorectal surgery were male gender, malnutrition, serum total protein less than $6 \mathrm{~g} / \mathrm{dl}$ and albumin less than $3.5 \mathrm{~g} / \mathrm{dl}$, hemoglobin less than $9.9 \mathrm{~g} \%$, blood transfusions, American Society of Anesthesiologists (ASA) score more than or equal to three, prolonged operating time and chronic steroid therapy. Local factors, which are associated with increased chance of $\mathrm{AL}$, are low rectal anastomosis, less than $6 \mathrm{~cm}$ from anal verge, neoadjuvant radiotherapy, intraperitoneal chemotherapy, Hyperthermic intraperitoneal chemotherapy and bevacizumab. In the present study, it was found that risk factors which reflect the general nutritional status of the patient such as hemoglobin, total protein, albumin had no association with the AL. Other risk factors such as neoadjuvant radiotherapy or chemotherapy, surgical techniques, duration of surgery, and chronic kidney disease were not studied in our study.

The present study showed that serum CRP value above $44.32 \mathrm{mg} / \mathrm{dl}$ on POD three can detect AL with sensitivity of $72.73 \%$, specificity of $66.13 \%$, positive predictive value of $30 \%$, negative predictive value of $75.93 \%$ and accuracy of $59.52 \%$. Since the negative predictive value of CRP was more (75.93\%), it can be used as a tool to rule out AL. The present study also showed that raised peri-operative TLC is also associated with AL.

The merits of this study are the risk factors associated with $\mathrm{AL}$ such as hemoglobin, total protein and albumin were also analyzed. The other causes of raised CRP and PCT such as wound infection was also considered and analyzed. The duration of follow up was also long i.e., 60 days to include delayed postoperative complications.

The limitation of this study is the high wound infection rate in the study population, which may be because of poor nutritional status of the patients and the malignant nature of the disease.

\section{CONCLUSION}

The plasmatic concentration of more than $44.32 \mathrm{mg} / \mathrm{dl}$ of CRP on POD three, and $>9470$ cells $/ \mathrm{mm}^{3}$ of postoperative TLC were found to detect the AL early with a high negative predictive value. So, this can be utilized for discharging patients early after elective gastrointestinal surgeries. However, serum procalcitonin was not found to be a predictor of anastomotic leak. Risk factors such as low serum total protein, albumin and hemoglobin were not associated with anastomotic leak.

Ethics Committee Approval: The approval for this study was obtained from Jawaharlal Institute of Postgraduate Medical Education and Research Ethics Committee (Decision no: JIP/IEC/2016/1040 Date: 16.02.2017).

Peer-review: Externally peer-reviewed.

Author Contributions: Concept - A.A., G.S.S., V.K.; Design - A.A., S.S., V.K.; Supervision -A.A., G.S.S., V.K.; Materials - D.J.A., O.H.S., V.B.; Data Collection and/or Processing - D.J.A., O.H.S.; Analysis and Interpretation - D.J.A.,O.H.S., V.B.; Literature Review - D.J.A., S.S., V.B.; Writing Manuscript - A.A., G.S.S., V.K.; Critical Reviews - A.A., G.S.S., S.S., V.K.

Conflict of Interest: The authors declare that they have no conflict of interest.

Financial Disclosure: The authors declared that this study has received no financial support.

\section{REFERENCES}

1. Shogan BD, An GC, Schardey HM, Matthews JB, Umanskiy K, Fleshman JW, et al. Proceedings of the first international summit on intestinal anastomotic leak, Chicago, Illinois, October 4-5, 2012. Surg Infect 2014; 15(5): 479-89. [CrossRef]

2. Nikolian VC, Kamdar NS, Regenbogen SE, Morris AM, Byrn JC, Suwanabol PA, et al. Anastomotic leak after colorectal resection: A population-based study of risk factors and hospital variation. Surgery 2017; 161(6): 1619-27. [CrossRef]

3. Park JK, Kim JJ, Moon SW. C-reactive protein for the early prediction of anastomotic leak after esophagectomy in both neoadjuvant and non-neoadjuvant therapy case: a propensity score matching analysis. J Thorac Dis 2017; 9(10): 3693-702. [CrossRef]

4. Hayati F, Azman ZAM, Nasuruddin DN, Mazlan L, Zakaria AD, Sagap I. Serum procalcitonin predicts anastomotic leaks in colorectal surgery. Asian Pac J Cancer Prev 2017; 18(7): 1821-5. [CrossRef]

5. Schaheen L, Blackmon SH, Nason KS. Optimal approach to the management of intrathoracic esophageal leak following esophagectomy: a systematic review. Am J Surg 2014; 208(4): 536-43. [CrossRef]

6. Morks AN, Ploeg RJ, Sijbrand Hofker H, Wiggers T, Havenga K. Late anastomotic leakage in colorectal surgery: a significant problem. Colorectal Dis Off J Assoc Coloproctology G B Irel 2013; 15(5): e271-5. [CrossRef]

7. Muñoz JL, Alvarez MO, Cuquerella V, Miranda E, Picó C, Flores R, et al. Procalcitonin and C-reactive protein as early markers of anastomotic leak after laparoscopic colorectal surgery within an enhanced recovery after surgery (ERAS) program. Surg Endosc 2018; 32(9): 4003-10. [CrossRef]

8. Garcia-Granero A, Frasson M, Flor-Lorente B, Blanco F, Puga R, Carratalá A, et al. Procalcitonin and C-reactive protein as early predictors of anastomotic leak in colorectal surgery: a prospective observational study. Dis Colon Rectum 2013; 56(4):475-83. [CrossRef] 
9. Aiolfi A, Asti E, Rausa E, Bonavina G, Bonitta G, Bonavina L. Use of $C$-reactive protein for the early prediction of anastomotic leak after esophagectomy: Systematic review and Bayesian meta-analysis. PloS One 2018; 13(12): e0209272. [CrossRef]

10. Gordon AC, Cross AJ, Foo EW, Roberts RH. C-reactive protein is a useful negative predictor of anastomotic leak in oesophago-gastric resection. ANZ J Surg 2018; 88(3): 223-7. [CrossRef]

11. Davis KA, Crow JA, Chambers HW, Meek EC, Chambers JE. Racial differences in paraoxonase-1 (PON1): a factor in the health of southerners? Environ Health Perspect 2009; 117(8): 1226-31. [CrossRef]

12. Jain S, Sinha S, Sharma SK, Samantaray JC, Aggrawal P, Vikram NK, et al. Procalcitonin as a prognostic marker for sepsis: a prospective observational study. BMC Res Notes 2014; 7: 458. [CrossRef]

13. Hill VL, Simpson VZ, Higgins JM, Hu Z, Stevens RA, Metcalf JA, et al. Evaluation of the performance of the sysmex xt-2000i hematology analyzer with whole bloods stored at room temperature. Lab Med 2009; 40(12): 709-18. [CrossRef]

14. Mao X, Shao J, Zhang B, Wang Y. Evaluating analytical quality in clinical biochemistry laboratory using Six Sigma. Biochem Medica 2018; 28(2). [CrossRef]
15. Gessler B, Eriksson O, Angenete E. Diagnosis, treatment, and consequences of anastomotic leakage in colorectal surgery. Int J Colorectal Dis 2017; 32(4): 549-56. [CrossRef]

16. Malya FU, Hasbahceci M, Tasci Y, Kadioglu H, Guzel M, Karatepe O, et al. The role of c-reactive protein in the early prediction of serious pancreatic fistula development after pancreaticoduodenectomy. Gastroenterol Res Pract 2018; 2018: 9157806. [CrossRef]

17. Hiyoshi M, Chijiiwa K, Fujii Y, Imamura N, Nagano M, Ohuchida J. Usefulness of drain amylase, serum C-reactive protein levels and body temperature to predict postoperative pancreatic fistula after pancreaticoduodenectomy. World J Surg 2013; 37(10): 243-42. [CrossRef]

18. Snijders HS, Wouters MWJM, van Leersum NJ, Kolfschoten NE, Henneman $D$, de Vries AC, et al. Meta-analysis of the risk for anastomotic leakage, the postoperative mortality caused by leakage in relation to the overall postoperative mortality. Surg Oncol 2012; 38(11): 1013-9. [CrossRef]

19. Vasiliu ECZ, Zarnescu NO, Costea R, Neagu S. Review of risk factors for anastomotic leakage in colorectal surgery. Chir Buchar Rom 2015; 110(4): 319-26. [CrossRef]

\section{ORIJINAL ÇALIŞMA-ÖZET}

Turk J Surg 2021; 37 (1): 22-27

\section{Elektif bağırsak cerrahisi sonrası anastomoz kaçağının erken tespiti için serum C-reaktif proteininin ve prokalsitoninin seri tetkiki: prospektif kohort çalışma}

Devarajan Jebin Aaron ${ }^{1}$, Amaranathan Anandhi ${ }^{1}$, Gubbi Shamanaa Sreenath ${ }^{1}$, Sathasivam Sureshkumar ${ }^{1}$, Oseen Hajilal Shaikh', Vairrappan Balasubramaniyan², Vikram Kate ${ }^{1}$

1 Jawaharlal Lisansüstü Tıbbi Eğitim ve Araştırma Enstitüsü, Cerrahi Anabilim Dalı, Puducherry, Hindistan

2 Jawaharlal Lisansüstü Tıbbi Eğitim ve Araştırma Enstitüsü, Biyokimya Anabilim Dalı, Puducherry, Hindistan

\section{ÖZET}

Giriş ve Amaç: Anastomoz kaçağı, özelikle de geç tanı konulduğunda cerrahi sonuçlarını kötü etkileyebilir. Bu çalışmada, anastomoz kaçağının postoperatif erken dönemde tespit edilmesi için C-reaktif protein (CRP) ve prokalsitonin (PCT) seri değerlendirmesi kullanılmıştır.

Gereç ve Yöntem: Anastomoz uygulanmış elektif gastroinstestinal cerrahi hastalarını içeren tek merkezli prospektif bir çalışma yürütüldü. İlk beş postoperatif günde C-reaktif protein (CRP) ve prokalsitonin (PCT) seri olarak incelendi. Hemoglobin, total protein, albümin ve beyaz küre sayısı gibi diğer parametreler perioperatif olarak not edildi. Hastalar anastomoz kaçağı, yara enfeksiyonu ve diğer septik odakları değerlendirmek üzere cerrahi sonrası 60. güne kadar takip edildi.

Bulgular: Çalışmaya 84 hasta dahil edildi. Anastomoz kaçağı oranı \%26,19 idi (22/84) ve anastomoz kaçağı grubunda 3/22 hasta kaybedildi. Yara enfeksiyon oranı \%23,81 idi. Anastomoz kaçağını tespit etmede CRP cut-off değeri 44,322 mg/dl iken duyarlılık \%72,73, özgüllük \%66,13 ve doğruluk \%59,74 olarak ölçüldü. Ölçülen serum prokalsitonin, hemoglobin, total protein ve albumin değerleri anastomoz kaçağının erken tespiti için yeterince duyarlı değildi.

Sonuç: Üçüncü postoperatif günde CRP ölçümü anastomoz kaçağını 44,32 mg/dl'lik cut-off değeri ile öngörebilir. Yüksek CRP değeri olan hastalarda erken taburculuğa karar vermeden önce anastomoz kaçağının elenmesi gerekmektedir.

Anahtar Kelimeler: C-reaktif protein, prokalsitonin, anastomoz kaçağ

Doi: $10.47717 /$ turkjsurg.2021.5102 